GRASAS Y ACEITES 67 (3)

July-September 2016, e141

ISSN-L: 0017-3495

doi: http://dx.doi.org/10.3989/gya.1236153

\title{
Nutritional quality of the seed oil in thirteen Asphodeline species (Xanthorrhoeaceae) from Turkey
}

\author{
G. Zengin ${ }^{\mathrm{a}, \bigotimes}$, A. Aktumsek ${ }^{\mathrm{b}}$, J. Girón-Calle ${ }^{\mathrm{b}}$, J. Vioque $^{\mathrm{b}}$ and C. Megías ${ }^{\mathrm{b}}$ \\ ${ }^{a}$ Department of Biology, Science Faculty, Selcuk University, 42250-Konya, Turkey \\ ${ }^{\mathrm{b}}$ Food Phytochemistry Department. Instituto de la Grasa (C.S.I.C.). Campus Universidad Pablo de Olavide, \\ Edificio 46, Ctra. de Utrera Km 1. 41013-Sevilla. Spain \\ ${ }^{\square}$ Corresponding author: gokhanzengin@selcuk.edu.tr
}

Submitted: 02 December 2015; Accepted: 16 February 2016

SUMMARY: The fatty acid composition of the seed oil from 13 Turkish Asphodeline species was analyzed. The seed oil content ranged between $0.9 \%$ and $4.6 \%$, and included 26 different fatty acids from $\mathrm{C}_{12: 0}$ to $\mathrm{C}_{22: 5}$. The most abundant saturated, monounsaturated, and polyunsaturated fatty acids were $\mathrm{C}_{16: 0}(5.7 \%$ to $23.7 \%$ of their total fatty acid content), $\mathrm{C}_{18: 1 \omega 9}(11.3 \%$ to $30.3 \%)$, and $\mathrm{C}_{18: 2 \omega 6}(49.2 \%$ to $66.1 \%)$. A tenuior subsp. tenuiflora, which had the highest content of unsaturated fatty acids, also had the best fatty acid profile from a nutritional point of view. Asphodeline seed oil composition was similar to that of local, related vegetables such as onion seeds. Asphodeline species, which are most frequently grown to use the leaves in salads, may also be a good source of seed oil with good nutritional properties. Results of a cluster analysis using data on the fatty acid composition are consistent with the taxonomic classification of genus Asphodeline.

KEYWORDS: Asphodeline; Fatty acid composition; Nutritional quality; Seed oil

RESUMEN: Calidad nutricional del aceite de semilla de trece especies Asphodeline (Xanthorrhoeaceae) procedentes de Turquía. Se ha analizado la composición en ácidos grasos del aceite de las semillas de 13 especies de Asphodeline de Turquía. El contenido en aceite de las semillas osciló entre el $0.9 \%$ y el $4.6 \%$ e incluyó 26 ácidos grasos distintos entre $\mathrm{C}_{12: 0}$ y $\mathrm{C}_{22: 5}$. Los ácidos grasos saturados, monoinsaturados y poliinsaturados más abundantes fueron $\mathrm{C}_{16: 0}(5.7 \%$ a $23.7 \%), \mathrm{C}_{18: 1 \omega 9}(11.3 \%$ a $30.3 \%)$ y $\mathrm{C}_{18: 2 \omega 6}(49.2 \%$ a $66.1 \%)$. A. tenuior subsp. tenuiflora, que presentó el contenido más alto en ácidos grasos insaturados, también tenía el mejor perfil en ácidos grasos desde un punto de vista nutricional. La composición del aceite de las semillas de Asphodeline fue similar a la de vegetales relacionados como la cebolla. Asphodeline, cuyas hojas son consumidas en ensaladas, puede representar también una buena fuente de aceite de las semillas con buenas propiedades nutricionales. Los resultados del análisis de grupos usando los datos de la composición en ácidos grasos son consistentes con la clasificación taxonómica del género Asphodeline.

PALABRAS CLAVE: Aceite de semillas; Asphodeline; Calidad nutricional; Composición en ácidos grasos

Citation/Cómo citar este artículo: Zengin G, Aktumsek A, Girón-Calle J, Vioque J, Megías C. 2016. Nutritional quality of the seed oil in thirteen Asphodeline species (Xanthorrhoeaceae) from Turkey. Grasas Aceites, 67 (3): e141. doi: http:// dx.doi.org/10.3989/gya.1236153.

Copyright: (C) 2016 CSIC. This is an open-access article distributed under the terms of the Creative Commons Attribution-Non Commercial (by-nc) Spain 3.0 Licence. 


\section{INTRODUCTION}

Asphodeline is an important genus belonging to the Xanthorrhoeaceae family. It includes 14 species and until recently had been classified within the Liliaceae family. Species belonging to Asphodeline are found in the Mediterranean Region, mainly in Middle-Eastern countries. They may be rhizomatous or stoloniferous perennial plants, biennial plants, or annual herbs, and they are found in diverse habitats including river banks, fallow fields, forest clearings, and rocky or clayey slopes. This genus is very well represented in Turkey, where it is known under the names Ciriş otu, Kiriş otu and Yayla çirişi, and includes 20 taxa, 12 of which are endemic (Mathews and Tuzlaci, 1984; Tuzlaci, 1987). Asphodeline taxonomy is complex and most species share similar morphological characteristics (Mathews and Tuzlaci, 1984).

Some Asphodeline species are traditionally used as food and in folk medicine in several countries including Turkey (Tuzlaci, 1985, Lazarova et al., 2009; Todorova et al., 2010). Thus, A. damascena subsp. damascena and A. tenuior subsp. tenuiflora are used to alleviate warts and heal wounds in Anatolian folk medicine. A. cilicica and A. globifera are used for the treatment of earaches and hemorrhoids, respectively (Tuzlaci, 1985). A. cilicica, A. damascena, A. globifera, A. lutea, and A. taurica leaves are consumed in salads in different regions of Turkey. Previous reports show that the protein in Asphodeline leaves has good nutritional properties (Zengin et al., 2012). These leaves are also rich in polyphenols with high antioxidant capacity (Lazarova et al., 2014). Nevertheless, the chemical composition of Asphodeline seeds is largely unknown. Considering that the seeds from vegetables related to Asphodeline including onions are eaten in several countries (Dini et al., 2008), Asphodeline species may well represent an interesting source of nutrients for human consumption. The aims of the present work were to evaluate the nutritional quality of Asphodeline seed oil, and to use the data on fatty acid composition for a cluster analysis in order to build a dendogram showing the relationships within the Asphodeline genera.

\section{MATERIALS AND METHODS}

\subsection{Plant materials}

Asphodeline seeds were collected in different regions of Turkey in 2013 at full maturity. Between five and ten plants were collected from each population. The location and altitude of populations are given in Table 1. Voucher specimens of each taxa were deposited in the KNYA Herbarium at the Department of Biology, Selcuk University, Konya, Turkey.

\subsection{Seed oil fatty acid analysis}

Extraction of the oil from ground seeds $(10 \mathrm{~g})$ was carried out for $6 \mathrm{~h}$ using petroleum ether and a Soxhlet apparatus. The solvent was removed using a rotary evaporator. Fatty acid methyl esters (FAME) were produced by saponification using $0,5 \mathrm{~N}$ sodium hydroxide in methanol, and transesterified using a $14 \% \mathrm{BF}_{3}-$ methanol solution (IUPAC, 1979). A Gas chromatographic analysis of FAME was carried out using a $6890 \mathrm{~N}$ model gas chromatograph equipped with an Agilent autosampler (7683) and a HP-88 capillary column $(100 \mathrm{~m} \times 0.25 \mathrm{~mm}$ i.d. x $0.2 \mu \mathrm{m})$. Helium was used as carrier gas at a $1 \mathrm{~mL} \cdot \mathrm{min}^{-1}$ flow rate. The column temperature regime was as follows: $60{ }^{\circ} \mathrm{C}$ for $1 \mathrm{~min}$, increase to $190^{\circ} \mathrm{C}$ at $20^{\circ} \mathrm{C} \cdot \mathrm{min}^{-1}$, $190{ }^{\circ} \mathrm{C}$ for $60 \mathrm{~min}$, increase to $220^{\circ} \mathrm{C}$ at $1^{\circ} \mathrm{C} \cdot \mathrm{min}^{-1}$, and $220^{\circ} \mathrm{C}$ for $10 \mathrm{~min}$. The injector and FID detector temperatures were 250 and $280{ }^{\circ} \mathrm{C}$, respectively. The injection volume and split ratio were $1 \mu \mathrm{L}$ and 40:1, respectively. FAMEs were identified by comparing their retention times with those of FAME standards (Alltech and Accu) and were quantified as percentages of total fatty acids. The results are given as average values of three GC analyses \pm SD.

Atherogenic index (AI) and thrombogenicity index (TI) were calculated according to Ulbricht and Southgate (1991) as follows:

$$
\begin{aligned}
\mathrm{AI}= & {\left[\mathrm{C}_{12: 0}+\left(4 \times \mathrm{C}_{14: 0}\right)+\mathrm{C}_{16: 0}\right] /[(\omega 6+\omega 3) \mathrm{PUFA}+} \\
& \left.\mathrm{C}_{18: 1}+\text { other MUFA }\right] \\
\mathrm{TI}= & {\left[\mathrm{C}_{14: 0}+\mathrm{C}_{16: 0}+\mathrm{C}_{18: 0}\right] /\left[0.5 \times \mathrm{C}_{18: 1}+0.5 \mathrm{x}\right. \text { other }} \\
& \text { MUFA }+0.5 \times \omega 6 \text { PUFA }+3 \times 13 \text { PUFA }+ \\
& (\omega 3 \text { PUFA } / \omega 6 \text { PUFA })] .
\end{aligned}
$$

\subsection{Cluster analysis}

A cluster analysis was performed using the furthest neighbor method based on a euclidean distance matrix using the Statgraphics 5.1 software.

\section{RESULTS AND DISCUSSION}

The oil content in Asphodeline seeds ranged from $0.92 \%$ in $A$. rigidifolia to $4.61 \%$ in $A$. liburnica (Table 2). More than $70 \%$ total fatty acids were unsaturated in all taxa (Table 2). The content in polyunsaturated fatty acids (PUFAs) ranged between $48.17 \%$ and $68.54 \%$ (Table 2). A. tenuior and $A$. sertachae had the highest and lowest content in UFA, $91.25 \%$ and $69.76 \%$, respectively. Saturated fatty acids were found at much lower concentrations, not higher than $30 \%$ in any case (Table 2).

The composition in saturated fatty acids, from $\mathrm{C}_{12: 0}$ to $\mathrm{C}_{22: 0}$, is shown in Table 3. Palmitic acid $\left(\mathrm{C}_{16: 0}\right)$ was the most abundant, although contents were quite variable, from $5.65 \%$ in $A$. tenuior up to $23.69 \%$ in $A$. sertachae. Stearic acid $\left(\mathrm{C}_{18: 0}\right)$ was 
TABLE 1. Collection sites of Asphodeline taxa

\begin{tabular}{|c|c|c|}
\hline Taxa & Location & Altitude (m) \\
\hline A. anatolica E. Tuzlaci (En) & $\begin{array}{l}\text { Isparta. Between Sarkikaraagac and Yenisarbademli. } 38^{\circ} 03^{\prime} 07^{\prime \prime} \mathrm{N} \text {; } \\
31^{\circ} 17^{\prime} 51^{\prime \prime} \mathrm{E} \text {. }\end{array}$ & 1140 \\
\hline A. baytopae E. Tuzlaci & $\begin{array}{l}\text { Mersin. Gulnar; between Gulnar and Aydincik. } 36^{\circ} 16^{\prime} 07^{\prime \prime} \text { N; } 33^{\circ} \\
22^{\prime} 11^{\prime} \text { E. }\end{array}$ & 750 \\
\hline A. cilicica E. Tuzlaci (En) & Adana. Between Catalan and Aladag. $37^{\circ} 27^{\prime} 37^{\prime \prime} \mathrm{N}$; $35^{\circ} 20^{\prime} 12^{\prime \prime}$ E. & 1080 \\
\hline A. globifera J. Gay ex Baker & Kayseri. Yaylali, zinc mine road. $38^{\circ} 00^{\prime} 33^{\prime \prime} \mathrm{N}$; $35^{\circ} 23^{\prime} 55^{\prime \prime} \mathrm{E}$ & 1170 \\
\hline $\begin{array}{l}\text { A. damascena (Boiss.) Baker subsp. } \\
\text { gigantea E. Tuzlaci (En) }\end{array}$ & $\begin{array}{l}\text { Gaziantep. Between Gaziantep and Narli; Incesu village. } 37^{\circ} 13^{\prime} 58^{\prime \prime} \\
\text { N; } 37^{\circ} 18^{\prime} 06^{\prime \prime} \text { E. }\end{array}$ & 870 \\
\hline $\begin{array}{l}\text { A. damascena (Boiss.) Baker subsp. ovoidea } \\
\text { E. Tuzlaci (En) }\end{array}$ & $\begin{array}{l}\text { Kahramanmaras. Between Kahramanmaras and Goksun. } 37^{\circ} 45^{\prime} \\
50^{\prime} \mathrm{N} ; 36^{\circ} 43^{\prime} 52^{\prime} \text { E. }\end{array}$ & 650 \\
\hline $\begin{array}{l}\text { A. damascena (Boiss.) Baker subsp. rugosa } \\
\text { E. Tuzlaci (En) }\end{array}$ & 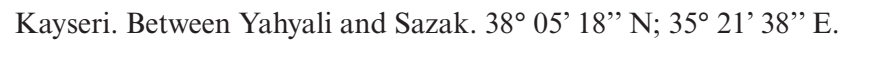 & 1200 \\
\hline A. liburnica (Scop.) Reichb. & $\begin{array}{l}\text { Canakkale. Between Gallipoli and Kesan; Koru mountain. } 40^{\circ} 42^{\prime} \\
29^{\prime \prime} \mathrm{N} ; 26^{\circ} 46^{\prime} 02^{\prime \prime} \text { E. }\end{array}$ & 370 \\
\hline A. lutea $(\mathrm{L})$ Reichb. & $\begin{array}{l}\text { Konya. Between Cevizli and Beysehir. } 37^{\circ} 10^{\prime} 27.3^{\prime \prime} \mathrm{N} ; 31^{\circ} 48^{\prime} 08^{\prime \prime} \\
\text { E. }\end{array}$ & 1200 \\
\hline A. peshmeniana E.Tuzlaci (En) & $\begin{array}{l}\text { Kahramanmaras. Göksun; between Ericek and Karadut. } 38^{\circ} 05^{\prime} 05^{\prime \prime} \\
\text { N; } 36^{\circ} 53^{\prime} 49^{\prime \prime} \text { E. }\end{array}$ & 1420 \\
\hline A. prismatocarpa J. Gay ex Baker (En) & 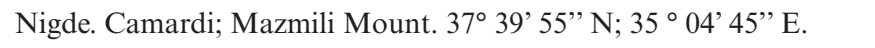 & 1970 \\
\hline A. rigidifolia (Boiss.) Baker (En) & $\begin{array}{l}\text { Konya. Between Konya and Beysehir; besides Altinapa Dam Lake. } \\
37^{\circ} 53^{\prime} 50^{\prime \prime} \mathrm{N} ; 32^{\circ} 18^{\prime} 28^{\prime \prime} \mathrm{E} \text {. }\end{array}$ & 1270 \\
\hline A. sertachae E.Tuzlaci (En) & $\begin{array}{l}\text { Antalya. Gazipasa, Ciglik village, Asarbasi. } 36^{\circ} 20^{\prime} 21^{\prime \prime} \mathrm{N} ; 32^{\circ} 31^{\prime} \\
47^{\prime} \text { E. }\end{array}$ & 1610 \\
\hline A. taurica (Pallas) Kunth & 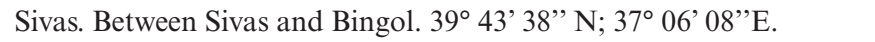 & 1380 \\
\hline $\begin{array}{l}\text { A. tenuior (Fischer) Ledeb. subsp. tenuiflora } \\
\text { (C. Koch) E. Tuzlaci var. tenuiflora (En) }\end{array}$ & $\begin{array}{l}\text { Malatya. Between Malatya and Darende. } 38^{\circ} 30^{\prime} 40^{\prime} \mathrm{N} \text {; } \\
37^{\circ} 31^{\prime} 19^{\prime \prime} \mathrm{E} \text {. }\end{array}$ & 1000 \\
\hline
\end{tabular}

(En): endemic to Turkey.

TABLE 2. Oil content, total polyunsatutared fatty acids ( PUFA), total unsaturated fatty acids ( $\Sigma$ UFA), total essential fatty acids ( $\Sigma$ EFA), total $\omega 3$ fatty acids $(\Sigma \omega 3)$ and total $\omega 6$ fatty acids $(\Sigma \omega 6)$, atherogenic index (AI) and thrombogenic index (TI) in Asphodeline seed oil

\begin{tabular}{lcccccccc}
\hline & Oil (\% & $\Sigma$ PUFA & $\Sigma$ UFA & $\Sigma$ EFA & $\Sigma \omega \mathbf{3}$ & $\Sigma \omega \mathbf{6}$ & AI & TI \\
\hline A. anatolica & 2.03 & 48.17 & 78.15 & 46.52 & 1.73 & 46.04 & 0.23 & 0.45 \\
A. baytopae & 3.12 & 63.85 & 83.43 & 62.73 & 0.47 & 63.11 & 0.16 & 0.32 \\
A. cilica & 2.13 & 55.53 & 82.65 & 54.04 & 1.26 & 54.20 & 0.16 & 0.32 \\
A. damascena subsp. damascena & 2.83 & 67.32 & 88.41 & 66.49 & 0.78 & 66.50 & 0.10 & 0.23 \\
A. damascena subsp. gigantea & 2.87 & 67.27 & 88.71 & 66.59 & 0.76 & 66.46 & 0.10 & 0.21 \\
A. damascena subsp. rugosa & 2.24 & 64.27 & 87.14 & 63.80 & 2.05 & 62.18 & 0.12 & 0.24 \\
A. globifera & 1.04 & 62.48 & 81.27 & 61.80 & 5.63 & 56.85 & 0.21 & 0.31 \\
A. liburnica & 4.61 & 60.85 & 88.53 & 60.29 & 0.34 & 60.47 & 0.10 & 0.23 \\
A. lutea & 3.11 & 57.82 & 87.14 & 57.23 & 0.52 & 57.28 & 0.11 & 0.27 \\
A. peshmeniana & 1.64 & 64.31 & 87.07 & 63.85 & 1.17 & 63.10 & 0.12 & 0.23 \\
A. prismatocarpa & 1.41 & 67.24 & 85.84 & 66.43 & 1.93 & 65.24 & 0.12 & 0.26 \\
A. rigidifolia & 0.92 & 61.14 & 75.77 & 60.34 & 4.39 & 56.69 & 0.27 & 0.44 \\
A. sertachae & 1.41 & 55.73 & 69.76 & 54.14 & 5.39 & 50.03 & 0.37 & 0.56 \\
A. taurica & 1.64 & 68.54 & 85.12 & 67.50 & 1.55 & 66.91 & 0.14 & 0.28 \\
A. tenuior subsp. tenuiflora & 4.52 & 58.91 & 91.25 & 58.45 & 0.92 & 57.95 & 0.08 & 0.16 \\
\hline
\end{tabular}




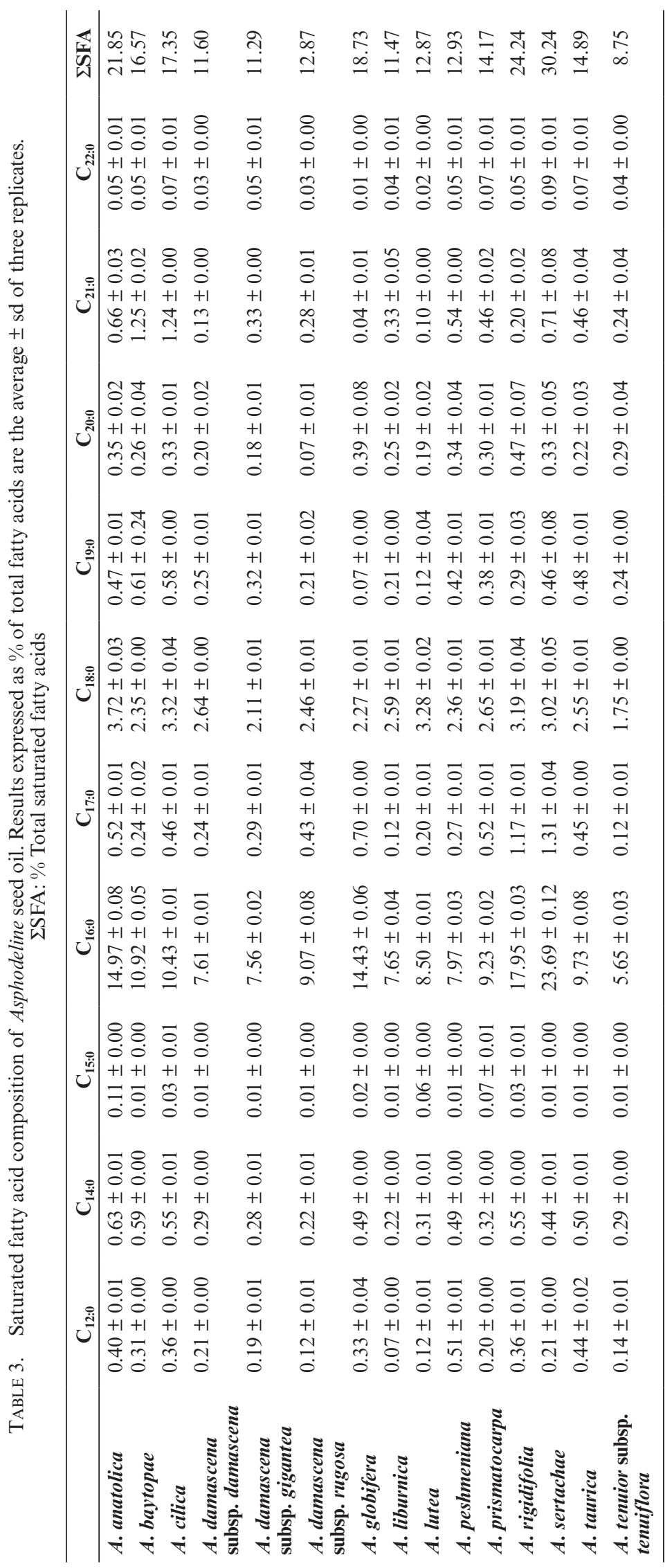


found at much lower concentrations, between 1.75\% in A. tenuior and $3.72 \%$ in A anatolica. The content of other saturated fatty acids rarely exceeded $1 \%$ in any taxa. Consequently, the content in total saturated fatty acids was also quite variable, varying between $8.75 \%$ in $A$. tenuior and $30.24 \%$ in $A$. sertachae. Species with low $\mathrm{C}_{18: 0}$ contents tend to have higher amounts of $\mathrm{C}_{16: 0}$, indicating a negative correlation between the contents in $\mathrm{C}_{16: 0}$ and $\mathrm{C}_{18: 0}$.

Monounsaturated fatty acids from $\mathrm{C}_{14: 1}$ up to $\mathrm{C}_{20: 1}$ were found in the seed oil (Table 4). The most abundant was oleic acid $\left(\mathrm{C}_{18: 1 \omega 9}\right)$ with contents ranging from $11.34 \%$ in $A$. sertachae to $30.27 \%$ in A. tenuior. The isomer $\mathrm{C}_{18: 1 \omega 11}$ was found at lower concentrations. The content in all other monounsaturated fatty acids did not exceeded 1\%. Polyunsaturated fatty acids ranged in length and unsaturations from $\mathrm{C}_{18: 2}$ to $\mathrm{C}_{22: 5}$ (Table 5). The essential fatty acid linoleic acid $\left(\mathrm{C}_{18: 206}\right)$ was the most abundant at contents ranging from $45.04 \%$ in $A$. anatolica to $66.1 \%$ in $A$. taurica. The content in $\mathrm{C}_{18: 1}$ was lower than the content in $\mathrm{C}_{18: 2}$ in all species. The essential linolenic acid $\left(\mathrm{C}_{18: 303}\right)$ was also relatively abundant in the Asphodeline species, especially in A. globifera, A. sertache, and A. rigidifolia where it was found at $5.36,4.97$, and $4.18 \%$, respectively.

These results on fatty acid composition are in agreement with those reported by other authors in related species. Hence, Yalcin et al. (2014) described the most abundant fatty acid in onion (Allium cepa L.) seed oil as linoleic acid at $49.4-60.7 \%$, followed by oleic and palmitic acids. Similar results were found by Reddy et al (2011) and Udayasekhara-Rao (1994), reporting that the most abundant fatty acids in onion seed oil were in decreasing order linoleic acid, oleic acid, palmitic acid, and stearic acid.

As shown in Table 2, the seeds from A. taurica, $A$. prismatocarpa, and $A$. damascena have the highest contents in essential fatty acids (EFA), while $A$. anatolica has the lowest. A. anatolica also has the lowest content in $\omega 6$ fatty acids, while $A$. taurica and $A$. damascena have the highest. The atherogenic and thrombogenic indexes define the potential of fats and oils to increase cardiovascular risk in humans. $A$. tenuior and $A$. damascena have the lowest atherogenic and thrombogenic indexes. These values are similar to those reported for the most popular edible oils, including sunflower, corn, soy, and olive oil (Castro-Bolanos et al., 2005). The highest atherogenic and thrombogenic indexes were found in the oil from A. sertachae, A. rigidifolia and A. anatolica. Hence, from a functional point of view, A. damascena, A. tenuior, and A. taurica have the best seed oil composition. The fact that the leaves from $A$. damascena and $A$. taurica are eaten in salads could facilitate the introduction of the seeds from these species in the human diet. Interestingly, the plants that have the worst seed oil fatty acid composition, namely $A$. anatolica, $A$. rigidifolia, and $A$. sertachae, are not used at all for human consumption.

Data on fatty acid composition were used to carry out a cluster analysis of the Asphodeline species.

TABLE 4. Monounsaturated fatty acid composition of Asphodeline seed oil. Results expressed as $\%$ of total fatty acids are the average \pm sd of three replicates. $\Sigma$ MUFA: $\%$ Total monounsaturated fatty acids

\begin{tabular}{|c|c|c|c|c|c|c|c|c|c|}
\hline & $C_{14: 1 \omega 5}$ & $\mathrm{C}_{15: 1 \omega 5}$ & $\mathrm{C}_{16: 1 \omega 7}$ & $\mathrm{C}_{17: 1 \omega 8}$ & $\mathrm{C}_{18: 1 \omega 9}$ & $C_{18: 1 \omega 11}$ & $C_{20: 1 \omega 9}$ & $\Sigma$ MUFA & $\underset{C_{18: 1 \omega 9}}{\Sigma \text { MUFA- }}$ \\
\hline A. anatolica & $0.01 \pm 0.00$ & $0.03 \pm 0.01$ & $0.13 \pm 0.01$ & $0.02 \pm 0.00$ & $24.02 \pm 0.01$ & $5.37 \pm 0.04$ & $0.42 \pm 0.07$ & 29.99 & 5.97 \\
\hline A. baytopae & $0.01 \pm 0.00$ & $0.04 \pm 0.01$ & $0.18 \pm 0.01$ & $0.03 \pm 0.01$ & $16.18 \pm 0.01$ & $2.54 \pm 0.01$ & $0.62 \pm 0.04$ & 19.58 & 3.40 \\
\hline A. cilica & $0.02 \pm 0.01$ & $0.03 \pm 0.00$ & $0.20 \pm 0.00$ & $0.08 \pm 0.01$ & $24.45 \pm 0.15$ & $1.82 \pm 0.04$ & $0.54 \pm 0.03$ & 27.13 & 2.68 \\
\hline $\begin{array}{l}\text { A. damascena } \\
\text { subsp. damascena }\end{array}$ & $0.01 \pm 0.00$ & $0.01 \pm 0.00$ & $0.15 \pm 0.00$ & $0.05 \pm 0.00$ & $20.15 \pm 0.01$ & $0.36 \pm 0.02$ & $0.37 \pm 0.02$ & 21.09 & 0.94 \\
\hline $\begin{array}{l}\text { A. damascena } \\
\text { subsp. gigantea }\end{array}$ & $0.01 \pm 0.00$ & $0.01 \pm 0.00$ & $0.09 \pm 0.00$ & $0.06 \pm 0.00$ & $20.55 \pm 0.00$ & $0.31 \pm 0.01$ & $0.41 \pm 0.01$ & 21.44 & 0.89 \\
\hline $\begin{array}{l}\text { A. damascena } \\
\text { subsp. rugosa }\end{array}$ & $0.01 \pm 0.00$ & $0.01 \pm 0.00$ & $0.08 \pm 0.01$ & $0.02 \pm 0.00$ & $21.92 \pm 0.04$ & $0.30 \pm 0.02$ & $0.54 \pm 0.04$ & 22.87 & 0.96 \\
\hline A. globifera & $0.01 \pm 0.00$ & $0.03 \pm 0.01$ & $0.28 \pm 0.00$ & $0.04 \pm 0.00$ & $18.14 \pm 0.01$ & $0.06 \pm 0.02$ & $0.24 \pm 0.04$ & 18.79 & 0.65 \\
\hline A. liburnica & $0.01 \pm 0.00$ & $0.01 \pm 0.00$ & $0.03 \pm 0.00$ & $0.01 \pm 0.00$ & $26.72 \pm 0.01$ & $0.32 \pm 0.03$ & $0.59 \pm 0.07$ & 27.69 & 0.97 \\
\hline A. lutea & $0.01 \pm 0.00$ & $0.03 \pm 0.01$ & $0.14 \pm 0.00$ & $0.02 \pm 0.00$ & $28.75 \pm 0.11$ & $0.15 \pm 0.01$ & $0.24 \pm 0.04$ & 29.32 & 0.58 \\
\hline A. peshmeniana & $0.01 \pm 0.00$ & $0.02 \pm 0.01$ & $0.15 \pm 0.04$ & $0.05 \pm 0.01$ & $21.05 \pm 0.00$ & $0.74 \pm 0.01$ & $0.76 \pm 0.01$ & 22.76 & 1.71 \\
\hline A. prismatocarpa & $0.04 \pm 0.02$ & $0.11 \pm 0.01$ & $0.31 \pm 0.00$ & $0.03 \pm 0.01$ & $16.79 \pm 0.00$ & $0.84 \pm 0.01$ & $0.50 \pm 0.02$ & 18.60 & 1.81 \\
\hline A. rigidifolia & $0.02 \pm 0.01$ & $0.03 \pm 0.01$ & $0.25 \pm 0.01$ & $0.03 \pm 0.00$ & $13.77 \pm 0.01$ & $0.24 \pm 0.04$ & $0.31 \pm 0.02$ & 14.63 & 0.87 \\
\hline A. sertachae & $0.01 \pm 0.00$ & $0.02 \pm 0.01$ & $0.19 \pm 0.00$ & $0.02 \pm 0.00$ & $11.34 \pm 0.06$ & $1.48 \pm 0.01$ & $0.98 \pm 0.01$ & 14.03 & 2.69 \\
\hline A. taurica & $0.01 \pm 0.00$ & $0.07 \pm 0.01$ & $0.11 \pm 0.04$ & $0.03 \pm 0.01$ & $15.18 \pm 0.07$ & $0.88 \pm 0.16$ & $0.31 \pm 0.03$ & 16.58 & 1.40 \\
\hline $\begin{array}{l}\text { A. tenuior subsp. } \\
\text { tenuiflora }\end{array}$ & $0.01 \pm 0.00$ & $0.01 \pm 0.00$ & $0.16 \pm 0.01$ & $0.02 \pm 0.01$ & $30.27 \pm 0.02$ & $1.33 \pm 0.00$ & $0.56 \pm 0.00$ & 32.35 & 2.08 \\
\hline
\end{tabular}




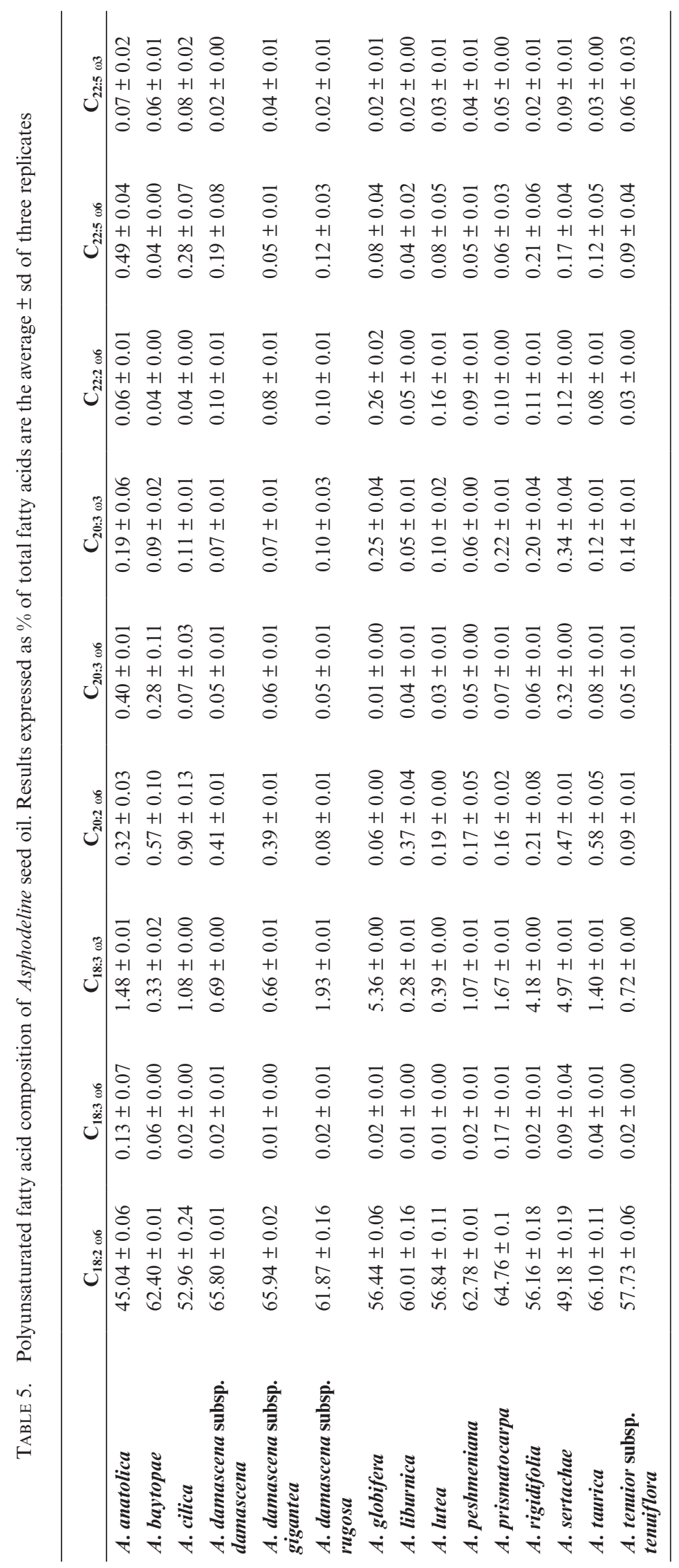




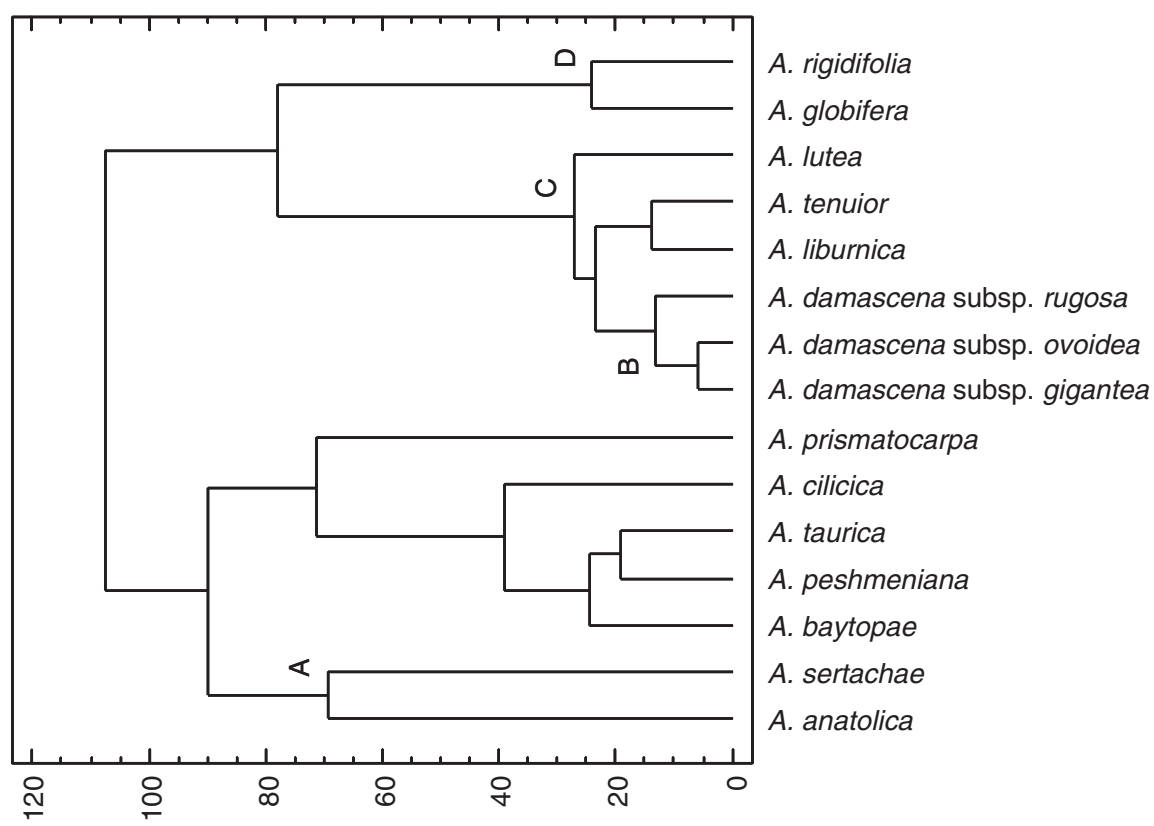

FIGURE 1. Dendogram produced by cluster analysis of data on fatty acid composition.

Figure 1 shows the resulting dendrogram, showing that the clusters generated according to fatty acid composition are consistent with the taxonomic classification previously established according to morphological characters (Tuzlaci, 1987). Thus, cluster A includes $A$. sertachae and A. anatolica, which share the same distribution area in the southern region of Turkey and a poor fatty acid profile from a nutritional point of view. Cluster B includes the three subspecies of $A$. damascena. In a previous study, A. damascena subspecies were also classified together in a dendrogram that was built according to the amino acid composition of the leaves (Zengin et al., 2012). Hence, these results show that subspecies of $A$. damascena are also chemically homogeneous. Cluster $\mathrm{C}$, in addition to $A$. damascena, includes three of the four species belonging to sect. Asphodeline. The fourth species belonging to this section is $A$. baytopae. Cluster D includes two taxonomically related species, $A$. rigidifolia and A. globifera, belonging to sect. Appendicigera .

It is concluded that in addition to other parts of the plants, especially leaves but also roots and flowers, the seeds from certain Asphodeline species could represent a good source of essential fatty acids for human nutrition. In fact, onion seeds, which share a similar fatty acid composition with Asphodeline seeds, are used in Indian foods (Yalcin et al., 2014). The use of Asphodeline seeds as a source of nutritious fatty acids would add to the nutritional value of the proteins and polyphenols in the leaves (Zengin et al., 2012; Lazarova et al., 2014).

\section{ACKNOWLEDGMENTS}

This work was carried out with the financial support of the Junta de Andalucía (Spain) to the Laboratory of Bioactive and Functional Components of Plant Products (Instituto de la Grasa, C.S.I.C.). Cristina Megias is recipient of a JAE-Doc (C.S.I.C.) contract from the "Junta para la Ampliación de Estudios" program (co-financed by the European Social Fund).

\section{REFERENCES}

Castro-Bolaños M, Herrera-Ramírez CH, Lutz-Cruz G. 2005. Composición, caracterización y potencial aterogénico de aceites, grasas y otros derivados producidos o comercializados en Costa Rica. Acta Med. Cost. 47, 1-9.

Dini I, Carlo Tenore G, Dini A. 2008. Chemical composition, nutritional value and antioxidant properties of Allium caepa L. var. tropeana (red onion) seeds. Food Chem. 107, 613-621. http://dx.doi.org/10.1016/j. foodchem.2007.08.053.

IUPAC. 1979. Standards methods for analysis of oils, fats and derivatives. In C. Paquot (Ed.) (6th ed), pp. 59-66). Oxford Pergamon Press.

Lazarova I, Marinova E, Todorova-Nikolova G, Kostova I. 2009. Antioxidant properties of Asphodeline lutea of Bulgarian origin. Riv. Ital. Sost. Gras. 86, 181-188.

Lazarova I, Zengin G, Aktumsek A, Gevrenova R, Ceylan R, Uysal S. 2014. HPLC-DAD analysis of phenolic compounds and antioxidant properties of Asphodeline lutea roots from Bulgaria and Turkey. Ind. Crops Prod. 61, 438-441. http://dx.doi.org/10.1016/j. indcrop.2014.07.044.

Mathews VA. Tuzlaci E. 1984. Asphodeline Reichb. In Davis PH. (Ed). Flora of Turkey and East Aegean Islands. Vol 8, Edinburgh University Press, pp 88-97. 
Reddy PN, Azeemoddin G, Rao SDT. 1989. Processing and analysis of onionseed (Allium cepa) and its fixed oil. J. Am. Oil Chem. Soc. 66, 365.

Todorova G, Lazarova I, Mikhova B, Kostova I. 2010. Anthraquinone, naphthalene and napthoquinone components of Asphodeline lutea. Chem. Nat. Comp. 46, 322-323.

Tuzlaci E. 1985. Çiriş Plants of Turkey. J. Pharmac. Univ. Marmara, 1, 69-89.

Tuzlaci E. 1987. Revision of the genus Asphodeline (Liliaceae). A new infrageneric classification. Candollea, 42, 559-576.

Udayasekhara-Rao P. 1994. Nutrient composition of some lessfamiliar oil seeds. Food Chem. 50, 379-382. http://dx.doi. org/10.1016/0308-8146(94)90208-9.
Ulbricht TLV, Southgate DAT. 1991. Coronary heart disease: seven dietary factors. The Lancet, 338, 985-992. http:// dx.doi.org/10.1016/0140-6736(91)91846-M

Yalcin H, Kavuncuoglu H. 2014. Physical, chemical and bioactive properties of onion (Allium cepa L.) seed and seed oil. J. Appl. Bot. Food Qual. 87, 87-92. http://dx.doi. org/10.5073/JABFQ.2014.087.013.

Zengin G, Aktumsek A, Guler GO, Cakmak YS, Girón-Calle J, Alaiz M, Vioque J. 2012. Nutritional quality of protein in the leaves of eleven Asphodeline species (Liliaceae) from Turkey. Food Chem. 135, 1360-1364. http://dx.doi. org/10.1016/j.foodchem.2012.05.084 